\title{
Harta Karun Itu Candi Bata Yang Unik
}

\author{
Baskoro Daru Tjahjono
}

Keywords: brick, temple, classic, hindu-buddha, description, cultural resource management

\section{How to Cite:}

Tjahjono, B. D. (2003). Harta Karun Itu Candi Bata Yang Unik. Berkala Arkeologi, 23(2), 61-69. https://doi.org/10.30883/jba.v23i2.876

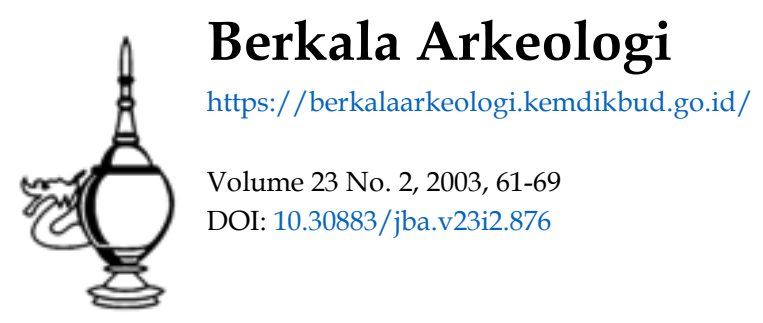

\section{cc) (1)(2)}

This work is licensed under a Creative Commons Attribution-NonCommercial-ShareAlike 4.0 International License. 


\section{HARTA KARUN ITU CANDI BATA YANG UNIK}

\section{Baskoro Daru Tjahjono}

Cerita tentang pencarian harta karun tak pernah ada habisnya. Banyak cerita tentang pencarian harta karun baik di media elektronik maupun cerita-cerita fiksi dalam bentuk komik maupun buku cerita. Dengan berbekal sebuah peta kuna dan kode-kode khusus sebagai petunjuk serta membawa perbekalan dan peralatan lengkap, para petualang menerobos hutan, mendaki gunung, menyeberang lautan menuju pulau terpencil sesuai petunjuk peta untuk mendapatkan harta itu. Dengan harapan mereka akan menjadi kaya dan namanyapun akan tercatat dalam sejarah sebagai petualang yang hebat atau paling tidak akan menjadi tokoh dalam cerita-cerita fiksi. Cerita petualangan semacam itu hingga kini memang sangat menarik baik bagi anak-anak maupun orang dewasa.

Ternyata petualangan mencari harta karun itu tidak hanya ada dalam cerita-cerita fiksi belaka melainkan juga ada dalam kehidupan nyata. Entah apa yang menjadi motivasi mereka untuk berburu harta karun pada situs-situs arkeologi. Sudah sejak lama situssitus arkeologi dijarah, karena diyakini di dalamnya tersimpan harta karun. Terutama candi-candi -- baik yang terbuat dari batu maupun bata -- biasanya ditemukan dalam keadaan porak-poranda karena dikira menyimpan harta.

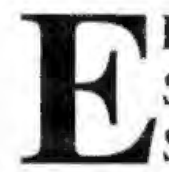
kskavasi Situs Candi Wurung

Sebuah situs yang terletak di Dusun Candi, Desa Menoreh, Kecamatan Salaman, Kabupaten Magelang pun tak luput dari penjarahan itu. Penduduk menyebut situs itu Candi Wurung, karena dianggap sebagai candi yang belum selesai dibangun. Beberapa tahun lalu situs yang terletak di tanah milik Hadi Prayitno itu digali oleh sekelompok orang. Masyarakat sekitar tidak tahu asal mereka dan maksud penggalian itu. Hanya berita dari mulut ke mulut tersiar kabar bahwa tujuan mereka adalah mencari harta karun. Entah ketemu entah tidak tetapi lubang bekas galian tanah itu mereka tinggalkan begitu saja. Situs itu sempat terbengkelai setelah terjadinya penggalian liar itu. Pemilik tanah pun tak tahu apa yang akan dia kerjakan, sehingga tanah sawah yang sebenarnya produktif itu dibiarkan saja tak ditanami apapun.

Ketika tim dari Balai Arkeologi Yogyakarta melakukan peninjauan ke situs tahun 2001 -- yang waktu itu kebetulan musim hujan -- tampak genangan air yang cukup dalam di bekas lubang galian yang masih menganga. Di permukaan, tanah bekas galian membentuk gundukan di bibir lubang. Di atasnya tergeletak dua buah yoni dari batu andesit -- salah satunya tinggal separuh - dan sebuah pecahan yoni yang tinggal 
seperempat bagian saja. Selain itu juga terdapat pecahan-pecahan bata kuna berukuran besar berserakan di atas tanah.

Bulan Agustus 2002 tim penelitian melakukan ekskavasi di situs itu. Kebetulan musim kemarau sehingga dasar lubang yang biasanya tergenang air pada musim hujan bisa tampak. Tim sempat ragu ketika melihat dasar lubang tidak ditemukan sisa-sisa benda apapun. Di benak mereka berkecamuk pertanyaan, apakah masih dapat menemukan struktur bangunan? Kelihatannya situs ini sudah hancur berantakan.

Ternyata ada sebersit harapan ketika beberapa anggota tim mengorek dasar lubang galian dan menemukan sederet bata yang masih tersusun. Nah itu sisa struktur bangunan, dari sini akan dikembangkan untuk melacak sisa-sisa struktur bangunan lainnya.

Ekskavasi dilakukan dengan menggunakan sistem grid dengan teknik spit. Areal situs seluas $20 \times 28 \mathrm{~m}^{2}$ itu dibuat grid dengan masing-masing kotak ekskavasi berukuran 2 x $2 \mathrm{~m}^{2}$. Masing-masing spit mempunyai interval $20 \mathrm{~cm}$. Karena permukaan tanah situs ini sudah tidak rata karena adanya lubang besar dan gundukan-gundukan tanah urug bekas galian itu maka seluruh pengukuran kedalaman benda temuan struktur bangunan dilakukan dari Datum Point (DP). DP terletak di kotak J1 yang berada di sebelah utara situs. Ketinggian DP $312,26 \mathrm{~m}$ dpal. berada $25 \mathrm{~cm}$ di atas permukaan tanah. Ekskavasi ini dilaksanakan selama 12 hari dan berhasil membuka 11 kotak ekskavasi, yaitu kotak-kotak H5, I7, J7, J8, K5, K6, K7, K8, L5, L6, dan L8. Pembukaan kotak-kotak tersebut disesuaikan dengan tujuannya.

Pertama-tama dilakukan penggalian untuk melacak sisa struktur bata yang telah ditampakkan melalui pengorekan tanah. Sisa-sisa struktur bata ternyata semakin melebar dengan susunan yang sangat rapi, semacam lantai bangunan. Di sela-sela struktur bata terdapat tatanan batu kali. Temuan ini sangat menarik, karena setelah membuka beberapa kotak ekskavasi kelihatan adanya deretan-deretan struktur bata yang diperkirakan merupakan sisa-sisa pondasi bangunan. Uniknya deretan-deretan struktur bata itu tidak semuanya sejajar dengan arah mata angin. Bangunan candi biasanya berdenah bujursangkar atau empat persegi panjang, sehingga masing-masing sisi pondasinya membujur barat-timur dan melintang utara-selatan.

Deretan-deretan pondasi yang ditemukan di situs Candi Wurung ini selain membujur barat-timur dan melintang utara-selatan juga ada yang serong sehingga seolah-olah memotong sudut bangunan. Ternyata pondasi-pondasi serong itu ada lima deret berjajar semakin keluar semakin panjang. Bagian sudut yang terpotong itu adalah sudut baratdaya. Di antara deretan-deretan pondasi bata itu diisi dengan remukanremukan bata yang dipadatkan di atasnya tatanan batu-batu kali yang selain sebagai isian kemungkinan juga berfungsi sebagai peresapan air tanah. Deretan pondasi serong ini juga ditemukan di sudut baratlaut, tetapi baru ditemukan tiga deret. 
Ekskavasi pada deretan pondasi-pondasi ini tidak dapat mencapai dasar struktur bata karena air tanah sudah keluar. Semakin dalam ekskavasi air tanah yang keluar semakin deras, sehingga ekskavasi dihentikan pada kedalaman $300 \mathrm{~cm}$ dari DP.

Bulan Agustus 2003 tim penelitian melakukan ekskavasi lagi di situs itu untuk mengungkap lebih jauh denah bangunan Candi Wurung. Ekskavasi tahap ini terutama ditujukan untuk mengungkap bagian pusat bangunan dan bagian denah yang berpola segiempat. Ekskavasi yang dilakukan selama 12 hari tersebut berhasil membuka 13 kotak ekskavasi, yaitu kotak D8, F6, F7, G7, H3, H4, H5, H7, I8, K9, K10, L6, dan L7.

Ekskavasi tahap ini berhasil mengungkap bagian pusat Candi Wurung. Di pusat candi ditemukan struktur bata melingkar dengan dengan diameter $2,5 \mathrm{~m}$. Akan tetapi struktur melingkar ini hanya separuh bagian barat, sedangkan yang separuh bagian timur belum dibuka. Selain struktur melingkar juga ditemukan struktur bata lurus yang ujung-ujungnya bertemu di tengah sehingga merupakan jari-jari lingkaran. Di antara jari-jari tersebut berisi tanah. Namun sebagian struktur baik yang melingkar maupun yang lurus ditemukan dalam keadaan rusak. Sebelum struktur bata ini ditemukan di atasnya terdapat banyak sekali runtuhan bata. Ekskavasi dihentikan pada kedalaman $285 \mathrm{~cm}$ karena air tanah sudah keluar dengan deras, sehingga untuk memperdalam lagi mengalami kesulitan. Struktur bangunan pada bagian ini belum mencapai dasar struktur.

Ekskavasi di sisi barat yang bertujuan untuk mengungkap denah bangunan yang berpola segiempat menemukan tiga buah struktur bata melintang utara-selatan dan tiga struktur bata membujur barat-timur. Salah satu struktur bata yang membujur barattimur mempunyai lebar $2,20 \mathrm{~m}$ berada pada sisi barat. Dasar struktur berada pada kedalaman $220 \mathrm{~cm}$ dari DP. Di atas struktur bata ini ditemukan sebuah batu candi berprofil klasik Jawa Tengah yang terdiri dari pelipit persegi, setengah lingkaran, dan sisi genta. Di bawah struktur ini tampak adanya struktur bata melingkar yang terdiri dari satu lapis bata disusun tegak. Struktur bata melingkar ini mempunyai diameter 80 $\mathrm{cm}$ dan bagian dasar struktur ini berada pada kedalaman $252 \mathrm{~cm}$ dari DP. Ketika tanah di dalam struktur bata yang melingkar itu dibuka ditemukan sebuah bata yang dibentuk hati di bagian tengahnya terdapat lingkaran, ujung hati tersebut digores sehingga membentuk cekungan.

Struktur-struktur bata itu didirikan di atas tatanan batu-batu kali. Di antara strukturstruktur bata juga terdapat batu-batu isian, di bawah batu-batu isian itu terdapat remukan bata yang dipadatkan.

Ekskavasi di sisi selatan yang bertujuan untuk mengetahui kelanjutan struktur bata menyerong di sudut baratdaya, berhasil menemukan struktur menyerong yang paling 
luar dan struktur bata membujur barat-timur. Di selatan struktur bata barat-timur dan menyerong ini ditemukan struktur lantai bata.

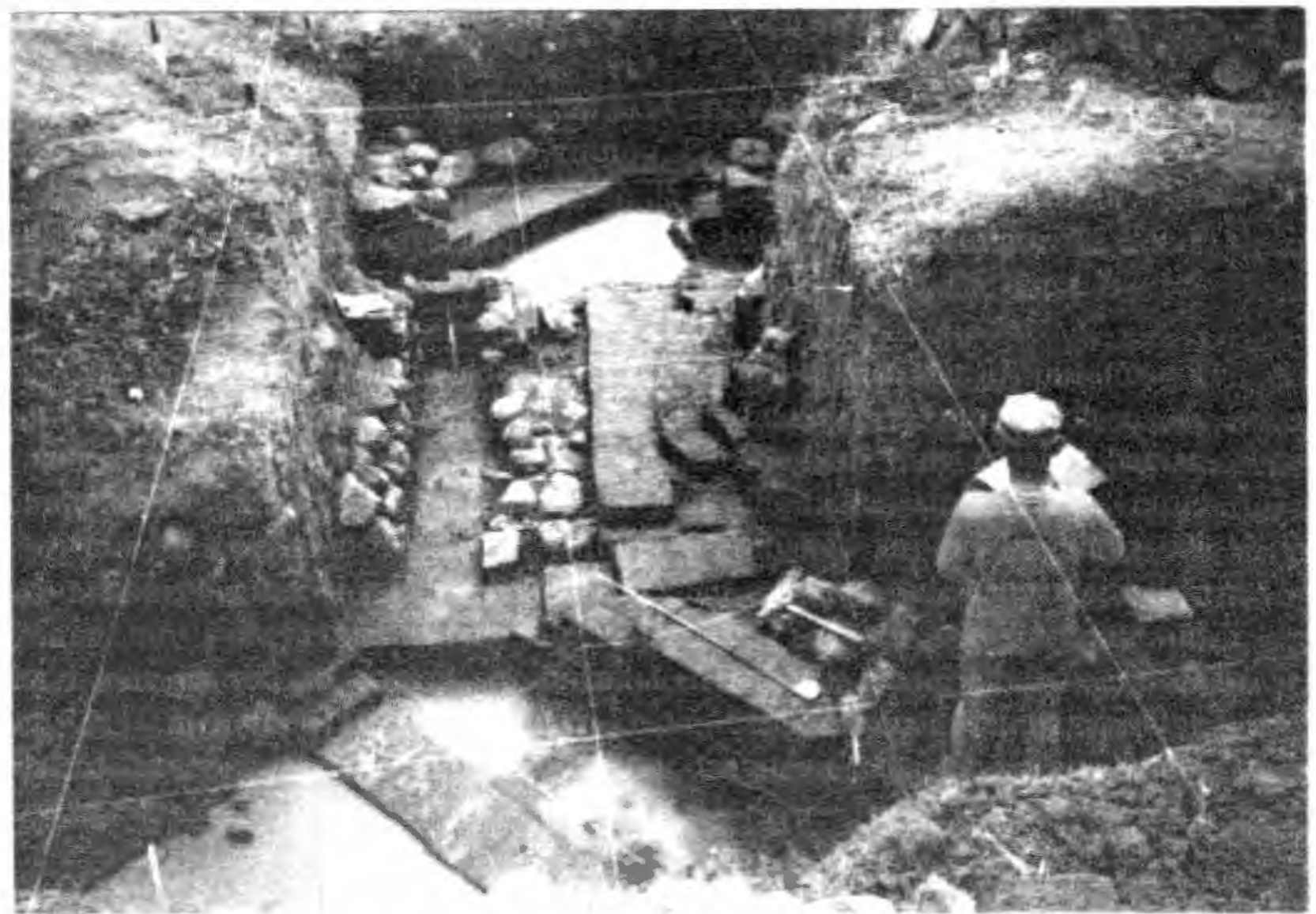

\section{A} rsitektur Candi Wurung

Candi adalah bangunan suci tempat pemujaan dewa. Hal ini telah ditegaskan oleh Soekmono dalam disertasinya yang berjudul Candi Fungsi dan Pengertiannya (Soekmono, 1974). Candi melambangkan Mahameru, yaitu gunung yang menjadi pusat alam semesta. Bangunan candi yang biasanya terdiri atas tiga bagian, yaitu kaki, tubuh, dan atap melambangkan tiga dunia, yaitu bhurloka, bhuwarloka, dan swarloka (Stutterheim, 1937; Boechari, 1978).

Ekskavasi di situs Candi Wurung baru berhasil menampakkan sebagian denah candi yang terbuat dari bata. Berdasarkan data tersebut dilakukan rekonstruksi di atas kertas. Hasilnya menunjukkan bahwa bangunan ini diperkirakan berdenah segi delapan dan kemungkinan berundak-undak/ berteras-teras dengan luas $11 \times 11 \mathrm{~m}^{2}$. Denah segi delapan ini terdiri dari teras-teras yang berjumlah 4 buah dengan bagian tengahnya berbentuk lingkaran dengan jari-jari berdiameter $2,5 \mathrm{~m}$, yang kemungkiman sebagai pusat bangunan. 
Bagian tengah struktur bangunan berupa lantai bata yang disusun berlapis-lapis ke atas. Setiap lapis mempunyai susunan bata yang berbeda-beda, demikian juga bentuk batanya tidak selalu empat persegi panjang. Pada tepi lantai susunannya lurus, sedangkan ke tengah di susun melingkar dan di pusatnya berbentuk lingkaran dengan jari-jari.

Bagian tengah bangunan ini dikelilingi oleh pondasi-pondasi/ struktur-struktur bata berbentuk segi delapan sebanyak empat buah. Masing-masing struktur segi delapan ini mempunyai interval antara $40-50 \mathrm{~cm}$. Lapisan bata masing-masing pondasi atau struktur bangunan ini bervariasi karena sebagian besar sudah rusak. Ada yang tinggal tiga lapis ada yang enam lapis, dan ada bagian yang masih tersisa cukup banyak sampai sepuluh lapis bata. Di antara pondasi-pondasi bata ini terdapat tatanan-tatanan batu kali, di bawah tatanan batu kali terdapat remukan bata yang dipadatkan, paling bawah adalah tanah. Kemungkinan bagian-bagian yang berupa tanah dulunya juga berisi tatanan batu-batu kali dan remukan bata yang dipadatkan tetapi sudah dibongkar orang. Hal ini tampak dari adanya sisa-sisa batu kali di antara struktur bata yang sebagian berupa tanah itu. Di atas tatanan batu kali ini kemungkinan terdapat lantai bata yang merupakan teras-teras bangunan. Sayang sekali sebagian besar lantai bata ini sudah hilang.

Candi ini tinggal bagian kaki, sedangkan tubuh serta atapnya sudah runtuh sehingga bentuk secara vertikal belum dapat diketahui. Yang menarik dari denah candi ini bahwa di luar denah segi delapan masih dikelilingi oleh denah yang berpola dasar segiempat. Denah berpola segiempat ini juga berteras dan mempunyai penampil di bagian barat bangunan. Penampil pertama mempunyai panjang $5 \mathrm{~m}$, sedangkan dari titik pusat lingkaran berukuran $7 \mathrm{~m}$. Penampil kedua di sebelah baratnya mempunyai panjang $9 \mathrm{~m}$, dari titik pusat lingkaran berukuran $10 \mathrm{~m}$. Di tengah penampil ini terdapat struktur bata memanjang ke barat yang diperkirakan sebagai jalan masuk ke candi dari sisi barat. Belum dapat diketahui apakah jalan semacam ini juga terdapat di tiga sisi yang lain, karena di ketiga sisi lain belum dilakukan ekskavasi. Jika bentuk denah bangunan ini simetris maka kemungkinan di ketiga sisi lainnya juga terdapat jalan masuk. Jika benar demikian maka denah paling luar diperkirakan berukuran $20 \mathrm{x}$ $20 \mathrm{~m}^{2}$.

Melihat sebagian denah bangunan ini kemungkinan bangunan ini mempunyai bentuk simetris. Bagian denah yang sudah tampak simetris adalah sisi utara dan sisi selatan. Sedangkan sisi timur sebagian besar belum diekskavasi sehingga denah bagian ini belum tampak, tetapi kemungkinan juga simetris dengan sisi barat. Memang masih banyak bagian-bagian denah bangunan ini yang belum terungkap dalam penelitian ini. Sehingga denah secara keseluruhan belum dapat diketahui secara pasti. 
Namun pola bangunan semacam itu sangat unik dan jarang bahkan mungkin belum pernah dijumpai di Jawa Tengah, khususnya untuk candi bata. Candi yang mempunyai denah mendekati pola semacam itu adalah Candi Borobudur. Candi Borobudur mempunyai pola dasar denah paling luar segiempat dengan penampil-penampil pada keempat sisinya dan bentuk lingkaran-lingkaran. Bentuk denah segiempat terdiri dari enam teras yang masing-masing mempunyai lorong untuk melakukan prosesi keagamaan. Bentuk denah lingkaran terdiri dari tiga teras dengan stupa-stupa kecil yang berisi arca-arca Buddha dan sebuah stupa besar sebagai puncaknya.

Jika diamati dari bentuknya yang mempunyai pola menyerupai Candi Borobudur, Candi Wurung kemungkinan merupakan sebuah bangunan suci agama Buddha. Pola semacam itu merupakan pola sebuah mandala - sebagaimana halnya Candi Borobudur -- yaitu suatu bangunan berbentuk diagram magis yang berfungsi sebagai sarana meditasi. Tetapi adanya dua buah yoni yang ditemukan di permukaan tanah menunjukkan adanya unsur-unsur agama Hindu. Keberadaan yoni di situs tersebut memang belum jelas, apakah asli di lokasi itu ataukah berasal dari tempat lain. Bentuk denah seperti itu tidak lazim digunakan pada candi-candi berlatar belakang agama Hindu yang biasanya berbentuk segiempat. Mungkin saja yoni-yoni itu tidak berasal dari tempat ini (in-situ) sebab keletakan yoni-yoni itu tidak menyatu (intact) dengan struktur bangunan di bawahnya.

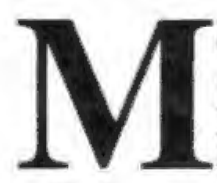

\section{otivasi Religi}

Pada masanya kira-kira abad VIII - X M, masyarakat di sekitar candi ini khususnya dan masyarakat Jawa Tengah umumnya sangat kuat kehidupan religiusnya. Kuatnya dorongan kehidupan religius itu tampak dalam semangatnya untuk membangun bangunan-bangunan suci, yang kini sebagian besar tinggal bekasbekasnya. Kesungguhan mereka dalam membangun bangunan-bangunan suci tidak saja dilihat dari bentuknya yang megah dan hiasannya yang raya, tetapi juga dari keunikan, kekhasan, dan juga dari teknik penyusunan bata atau batunya. Selain bakti mereka kepada raja yang berkuasa pada masa itu semangat mereka membangun candi terutama didorong oleh motivasi religius. Salah satu raja Dinasti Çailendra yang berkuasa di Jawa Tengah yang cukup banyak mendirikan bangunan suci adalah Rakai Panangkaran. Raja ini mendirikan candi-candi kerajaan untuk ibadah agama Buddha, diantaranya adalah Candi Kalasan yang tertulis dalam prasasti Kalasan tahun 778 M, Candi Sewu untuk pemujaan Manjusri seperti tercatat dalam Prasasti Kelurak tahun $782 \mathrm{M}$, Candi Plaosan Lor yang melambangkan kesatuan kerajaan, Candi Borobudur untuk pemujaan pendiri dinasti Çailendra, dan sebuah wihara di bukit Ratu Boko yang didirikan 8 tahun setelah turun tahta sebagaimana tertulis dalam prasasti Abhayagiriwihara tahun 792 M (Pusponegoro, 1984). 
Candi Wurung jelas mempunyai kekhasan dalam bentuk yang dapat dilihat dari keunikan denahnya. Selain itu teknik penyusunan bata -- khususnya pada lantainya juga menunjukkan keunikan dan teknik yang tinggi. Dari segi bentuk, denah bangunan seperti Candi Wurung ini jarang sekali ditemukan, bahkan mungkin satu-satunya yang ditemukan di Indonesia. Sebuah bangunan yang mempunyai pola yang agak mirip dengan pola denah demikian hanyalah Candi Borobudur. Tetapi Candi Borobudur terbuat dari batu andesit dan bagian tengah yang merupakan teras-teras paling atas tidak berbentuk segi delapan melainkan lingkaran. Dari cetakan batanya yang tampak pada struktur lantai melingkar terlihat adanya beberapa bentuk cetakan bata, selain empat persegi panjang ditemukan bentuk-bentuk yang lain seperti bentuk segitiga dan trapisium yang kadang-kadang ukurannya berbeda-beda. Tampak sekali bentukbentuk tersebut merupakan hasil pencetakan dan pembakaran, bukan hasil pemangkasan setelah bata dibakar. Jelas, bangunan tersebut memerlukan kecermatan yang tinggi dalam perancangan hingga pembangunannya. Ditemukan juga lantai bangunan yang terdiri dari beberapa lapis bata, masing-masing lapis mempunyai susunan bata yang berbeda. Ini menunjukkan bahwa perancangannyapun sangat rumit. Masalahnya bagaimana mereka merancang bangunan itu dan pada media apa mereka membuat gambar rancang bangun tersebut.

Apa motivasi mereka membuat karya yang megah dan adiluhung itu, yang memerlukan kecermatan dan teknik tinggi? Karya besar itu tentu memerlukan biaya tinggi pada waktu itu dan juga tenaga kerja yang besar. Tentu ada motivasi yang kuat yang mampu menggerakkan mereka. Motivasi itu tidak lain adalah kehidupan religius yang sangat kuat. Abad VIII sampai X M Jawa Tengah dikenal sebagai pusat kekuasaan masa klasik atau masa pengaruh budaya Hindu. Masa itu juga dikenal sebagai masa keemasan atau puncak pengaruh budaya yang berasal dari India itu. Mereka mendirikan bangunan-bangunan suci yang megah dan besar seperti Candi Borobudur, Candi Mendut, Candi Prambanan, Candi Sewu, Candi Kalasan, dan lainlain bukan semata-mata untuk menunjukkan kebesaran dan kekuasaan mereka, tetapi sebagai persembahan kepada dewa-dewa yang mereka puja.

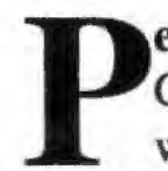
erlakuan terhadap Warisan Nenek Moyang Candi dan juga benda-benda cagar budaya (BCB) lain sebenarnya adalah harta warisan nenek moyang yang sangat berharga. Harta yang berharga itu tidak terletak pada nilai ekonomisnya tetapi terutama pada nilai sejarahnya, walaupun ada juga $\mathrm{BCB}$ yang mempunyai nilai ekonomis tinggi. $\mathrm{BCB}$ adalah bukti otentik adanya aktivitas manusia masa lalu yang mungkin tidak tercatat dalam buku-buku sejarah. Catatan-catatan sejarah masa lalu pun memerlukan bukti-bukti arkeologis yang akan menunjukkan peristiwa nyata pada masa itu. Sehingga pelestarian BCB sangat penting bagi penyusunan sejarah masa lalu manusia. 
Apa sebenarnya yang melatarbelakangi pencarian harta karun di situs-situs arkeologi? Apakah karena situs-situs itu dianggap angker sehingga digunakan untuk menyimpan harta benda oleh raja atau masyarakat masa lalu? Ataukah ada cerita-cerita bahwa di sumuran candi tersimpan harta benda berupa emas dan lain-lain? Yang tahu adalah mereka sendiri. Yang jelas pembongkaran candi-candi untuk dicari harta karunnya sudah berlangsung lama, karena memang banyak situs yang belum ada juru peliharanya sehingga keamanannya belum terjaga. Sebenarnya tidak hanya pencarian harta karun yang dapat merusak situs tetapi juga pencurian BCB yang biasanya berupa arca-arca pun masih marak terjadi. Jika hal ini dibiarkan saja tentunya akan banyak data sejarah yang hilang.

Untuk mengamankan seluruh situs di Indonesia, khususnya di Jawa tentu diperlukan biaya yang sangat besar dan tenaga yang sangat banyak. Apakah mampu jika semuanya dibebankan pemerintah lewat institusi yang berwenang? Tentunya diperlukan peran serta masyarakat luas khususnya masyarakat di sekitar situs untuk ikut menjaga dan mengamankan harta warisan nenek moyang itu. Agar masyarakat ikut merasa memiliki warisan nenek moyang itu tentunya pemerintah harus aktif memberi pengertian-pengertian tentang pentingnya $\mathrm{BCB}$, tidak saja bagi penulisan sejarah tetapi juga membuktikan bahwa nenek moyang kita pada masa itu telah mempunyai budaya tinggi.

Selain dilestarikan, BCB yang masih memungkinkan untuk dipugar dapat dimanfaatkan untuk kepentingan yang lebih luas seperti pariwisata dan lain-lain. Dengan demikian warisan nenek moyang itu sebenamya merupakan aset budaya yang sangat berharga. Terutama di era otonomi daerah ini aset-aset budaya itu dapat dikembangkan untuk meningkatkan PAD. Termasuk Candi Wurung.

\section{KEPUSTAKAAN}

Boechari, Bahan Kajian Arkeologi untuk Pengajaran Sejarah, Majalah Arkeologi Th. II, No. I, September, 1978.

Poesponegoro, Marwati Djoened, dan Nugroho Notosusanto, Sejarah Nasional Indonesia II, Jakarta: P.N. Balai Pustaka, 1984.

Soekmono, Candi Fungsi dan Pengertiannya, Disertasi, Universitas Indonesia, Jakarta, 1974.

Stutterheim, W.F., He Zinrijke Waterwerk van Djalatoenda, TBG LXVII, hlm. 173$216,1937$. 
Gambar Candi Wurung

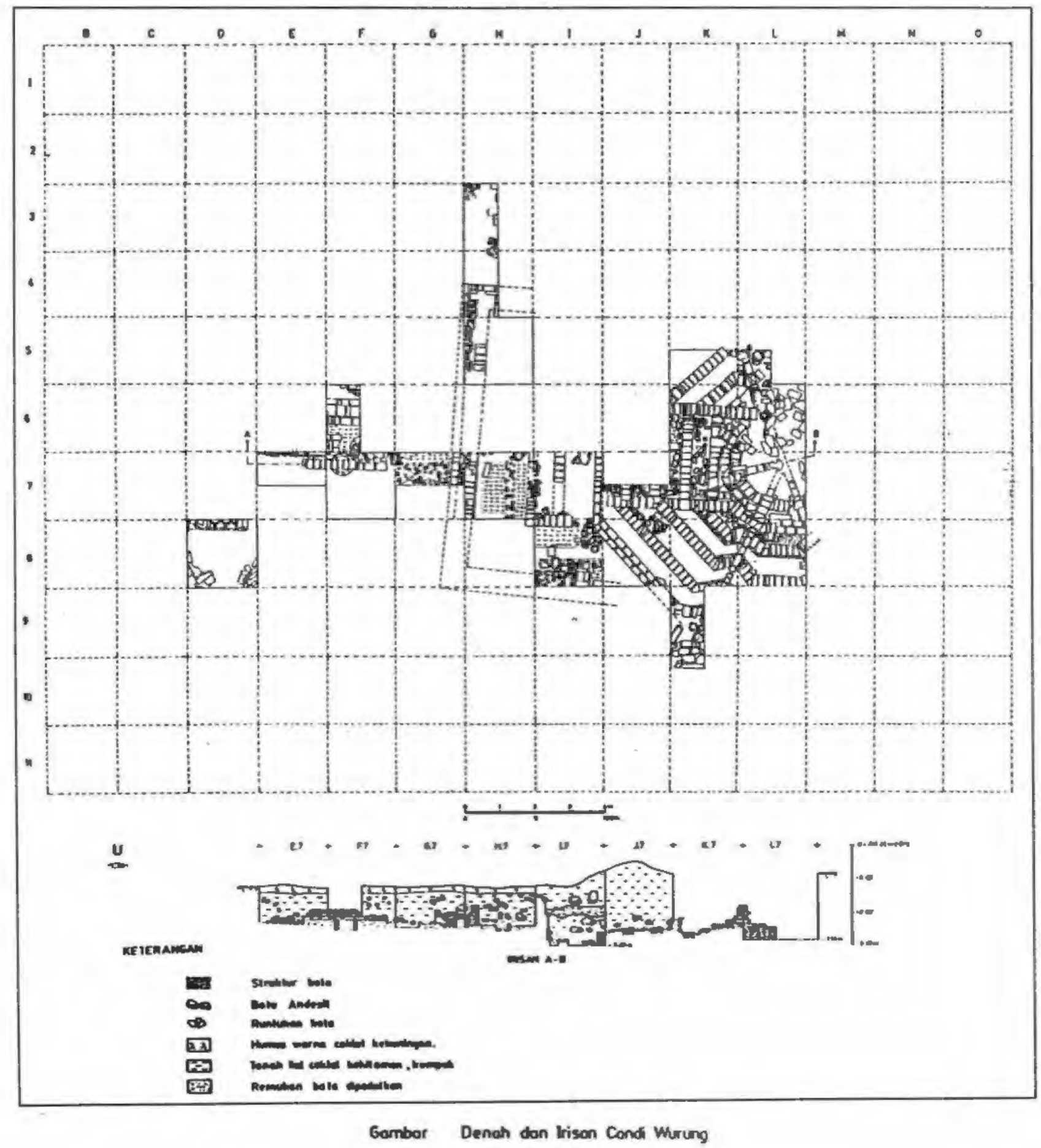

